\title{
A Proposal for State Funding of Municipal Tort Liability
}

\author{
James R. Hackney, Jr.
}

Recent increases in municipal insurance premiums ${ }^{1}$ have threatened to force some municipalities to go without liability insurance and risk bankruptcy. ${ }^{2}$ In response, several state legislatures are instituting tort reform and trying to ensure that municipalities receive adequate coverage for tort liability. ${ }^{3}$ These plans indicate increasing recognition of the problem, but

1. See Richland, Municipal Law: Local Government Liability Insurance and Tort Reform, N.Y.L.J., May 22, 1986, at 1 ("over 163 towns in New York State reported a premium increase of up to 100\%; over 41 towns reported an increase of up to $400 \%$ "); N.Y. Times, Mar. 4, 1986, at A26, col. 1 (editorial) (California's Orange County experienced six-fold increase in premiums); Sawyer, How a Good Town Became a Bad Risk, Wash. Post, Feb. 25, 1986, at A6, col. 6 (insurance premium for Schaghticoke, N.Y., increased $400 \%$ in course of one year).

2. Wall St. J., Apr. 16, 1986, at 41, col. 2 (reporting on "indications that 'quite a few' New Jersey municipalities can't get insurance"); Sullivan, U.S., States Seeking Ways to End Liability Insurance Crisis, Christian Sci. Monitor, Mar. 7, 1986, at 4, col. 3 (Blue Lake, Cal., lost its liability insurance policy and flew flag upside down as signal of distress); Wolinsky, Insurance Crisis Forecast for Most California Cities, L.A. Times, Feb. 28, 1986, at 3, col. 3 (estimating that two-thirds of California cities will be forced to go without liability coverage, while 43 cities already lack coverage); see also N.Y. Times, Mar. 4, 1986, at A26, col. 1 (editorial) (discussing need for proposals to smooth out effects of insurance business cycles); telephone interview with Mark Wasser, General Counsel to California Local Agency Self-Insurance Authority (Jan. 25, 1988) [hereinafter Wasser Interview] (stating that joint insurance pools were formed in response to cyclical nature of commercial insurance rates).

3. See Blodgett, Premium Hikes Stun Municipalities, A.B.A. J., July, 1986, at 48, 51 (1986) (reform of state tort systems expected in reaction to liability crisis); Priest, The Current Insurance Crisis and Modern Tort Law, 96 YALE L.J. 1521, 1587-89 (1987) (discussing tort reform); Wash. Post, Nov. 20, 1987, at C4, col. 1 (Virginia facing problems regarding liability insurance despite prior legislative action); Weintraub, 9 Bills Limiting Governmental Liability Pass Key State Panels, L.A. Times, Aug. 25, 1987, at 3, col. 2 (legislation passed to limit state and local government liability); Pasztor, White House Switches Focus to States in Bid for Liability-Insurance Revisions, Wall St. J., Mar. 27, 1987, at 48, col. 2 (in 1986, "30 states adopted laws that in some way limit liability claims"); Richland, supra note 1, at 2, col. 3 (discussing New York state proposal to amend rule of joint and several liability, and abolish collateral-source rule in reaction to insurance crisis); Sullivan, supra note 2, at 4, col. 1 (as of March 1986, 44 states with legislatures in session had tort reform bills pending); N.Y. Times, Mar. 4, 1986, at A26, col. 1 (editorial) (insurers call for tort reform to limit local government liability).

In California, a bill calling for a state insurance pool was recently passed by the state assembly. Cat. Gov't Code $\$ \S 6599.01-.41$ (West Supp. 1988). Under the California law, a state-instituted liability fund, administered through the Local Agency Self-Insurance Authority ("LASIA"), provides municipalities with insurance coverage for all tort liability over $\$ 1,000,000$ and under $\$ 25,000,000$ not met by private insurers. The fund is supported by premiums paid by municipalities, membership fees, and interest earned on money in the fund. The fund and its administration are separate from the state government, and the state is not directly responsible for the fund or for torts committed by any municipality covered under the plan. The program's sponsor stressed that "Ip]ublic entities are among those most severely affected by the unavailability of liability insurance. Cities and counties are particularly affected because of their high contact with people who use public facilities, especially streets, highways, parks and beaches." D. Hauser, Liability: Local Agency Self-Insurance Authority 1 (Aug. 26, 
they do not provide a comprehensive solution to the frequent unavailability of municipal insurance. This Note proposes that state legislatures assume responsibility for funding municipal tort liability through their power to levy income taxes. Adopting this proposal would help provide a long-term solution to the effects of insurance cycles on municipalities, while furthering the goals of the tort system.

The modern tort system rests on three principal goals: loss spreading, ${ }^{5}$ compensation, ${ }^{6}$ and deterrence. ${ }^{7}$ These three principles provide bench marks against which to measure the desirability and success of reforms in tort law and financing tort compensation. This Note argues that state funding through income taxation would be better at spreading losses and providing compensation than the current system of funding municipal liability and would also assure at least an equal level of deterrence. In addition, other public policy goals, not directly related to tort law, would be better addressed under a system of state-funded insurance.

Section I of this Note presents a general theoretical discussion of the goals of tort law and the relationship between government liability and loss spreading. Section II examines the elements of municipal taxation, and argues that the prevailing system of self-insurance by municipal gov-

1986) (legislative analysis of LASIA) (on file with author).

Minnesota has instituted a system called the League of Minnesota Cities ("LMC"); like California's LASIA, it allows cities to insure jointly against liability. MINN. STAT. ANN. $\$ 471.982$ (West Supp. 1988). Membership in the LMC grew from approximately 80 municipalities in May 1981 to approximately 400 in October 1985. League of Minnesota Cities, at 1 (1986) (information packet distributed by LMC) (on file with author). The 400 LMC members comprise about half of Minnesota's 855 municipalities. Bureau of the Census, Statistical, AbSTract of the United STATES 1988, at 274 (1988).

In addition, statutory provisions in other states allow joint insurance by municipalities. FLA. STAT. ANN. \$ 768.28(14) (Harrison Supp. 1987); TENN. CodE ANN. \$29-20-401 (Supp. 1980); VA. CODE ANN. $\S \S 15.1-7.3: 1,15.1-21$ (1950 \& Supp. 1987).

New York State was recently forced to insure a tramway which runs between New York City's Roosevelt Island and Manhattan. When operators of the tramway could not afford an insurance rate increase from $\$ 800,000$ to $\$ 9,000,000$ a year, the state stepped in and self-insured the tramway service. Sorry, Your Policy Is Cancelled, TIME, Mar. 24, 1986, at 16, 18. In addition, New York's attorney general has proposed the creation of a state insurance fund. The fund would charge municipalities the lowest possible rates to provide personal liability and property damage insurance for local governments. The fund would cover only local governments with fewer than 125,000 residents. Aschkenasky, Bill Offers N.Y.S. Fund for Gov't Liability, NAT'L. UNDERWRITER, Feb. 14, 1986, at 4 , col. 1.

4. Municipal insurance, even when it is technically available, is often unaffordable; a solution to the insurance problem must address both availability and cost. See D. Hauser, supra note 3, at 1 (cities and counties are most affected by unavailability of insurance); telephone interview with Patrick J. McCormick, Legislative Analyst for Minnesota Senate (Dec. 1, 1987) (legislation for joint selfinsurance pools for cities grew out of concern about recurring lack of insurance coverage).

5. The goal of loss spreading is satisfied when the cost of an accident is not borne solely by the tortfeasor. G. Calabresi, The Costs of Accidents 39-45 (1970); see also infra note 11 .

6. G. Calabresi, supta note 5, at 44; see also W. Keeton, D. Dobbs, R. Keeton \& D. OWen, Prosser \& Keeton on The Law of Torts § 4, at 20 (5th ed. 1984); Stewart, Crisis in Tort Law? The Institutional Perspective, 54 U. CHI. L. REv. 184 (1987) (compensation is function of tort law).

7. See G. Calabresi, supta note 5, at 26-31, 68-69; see also W. KeEton, D. DobBs, R. KeETON \& D. OWEN, supra note $6, \S 4$, at $25-26$ (providing strong incentive to prevent harm is one reason for imposing liability). 
ernments is regressive. ${ }^{8}$ Therefore, the current system fails to spread losses proportionately. Section III outlines a state-funded system and proposes specific measures for its implementation. Section III also demonstrates how a system of state funding would avoid the regressive effects of municipal funding, while preserving adequate levels of deterrence and compensation. Section IV discusses other advantages and possible disadvantages of the proposal.

\section{TORt LaW and Municipal Liability}

\section{A. Principles of Tort Law}

Three primary goals of modern tort law are compensation, deterrence, and loss spreading.' Compensation, which focuses on the system's "payouts," is measured by the degree to which the victim is restored to the condition she was in before the tort occurred. Deterrence, which forces tortfeasors to absorb the cost of their harms, is measured by the extent to which a system discourages people from engaging in harmful activities. ${ }^{10}$ Loss spreading focuses on "pay-ins" to the tort system."

Loss spreading requires that individuals in society share the costs of accidents because society is better off if several members of society suffer small losses than if one member suffers a large loss. ${ }^{12}$ Therefore, the notion of loss spreading is premised on the idea that accident costs should be as evenly dispersed throughout society as possible.

8. A tax is regressive if lower-income individuals pay a larger proportion of their income in taxes than those with higher incomes. Under a progressive tax system, those with higher incomes bear a greater proportion of the tax burden. A progressive system of taxation conforms to the notion that tax rates should correlate with one's ability to pay. E. Browning \& J. Browning, Public Finance and the Price System 298-300 (1983); W. Gardner, Government Finance: National, StaTe, AND Local 51-52 (1978).

9. See supra notes 5-7. Some scholars elevate corrective justice to the level of a principle of tort law, or a constraint on the pursuit of other goals. See, e.g., Coleman, Corrective Justice and Wrongful Gain, 11 J. Legal Stun. 421 (1982). Even if corrective justice is a legitimate goal, it is addressed inadequately by the existing tort system. See Sugarman, Doing Away With Tort Law, 73 CALIF. L. REv. 555 (1985). Sugarman argues that the goal of corrective justice is ill-served by the fault system in three ways: (1) liability insurance and the rule of respondeat superior undercut the notion of corrective justice against an individual defendant; (2) victims frequently obtain funds for rehabilitation from other sources before suing; and (3) it is not a given that people really want the legal system to provide retribution for harms or think it capable of doing so. Id. at 603-04.

10. Deterrence can be accomplished in two ways: (1) "direct deterrence," through rules that help prevent accidents (regulation); and (2) "market deterrence," the forced internalization of the costs of accident-causing behavior (paying damages). Owen, Deterrence and Desert in Tort: $A$ Comment, 73 Calif. L. Rev. 667, 669 (1985); see also G. Calabresi, supra note 5, at 68, 69 (direct deterrence called "specific deterrence"; market deterrence called "general deterrence"). Incorporated in the idea of deterrence is the concept of fault-assigning punishment based on the quality of the injurer's damaging conduct. Finding fault and assessing damages are functions of tort law, rather than goals. $C f$. Owen, supra, at 665, 666 (stigmatizing particular behavior and assessing damages are functions of tort law).

11. Even if one does not accept loss spreading as a free-standing goal of tort law, it has become a major factor in the tort system because insurance is prevalent in our society. James, Accident Liability Reconsidered: The Impact of Liability Insurance, 57 YALE L.J. 549, 551 (1948) (widely held insurance means that tort liability is no longer shifted, but is distributed).

12. G. Calabresi, supra note 5 , at 39. 


\section{B. Government Liability and Loss Spreading}

In exploring the relationship between government liability ${ }^{13}$ and loss spreading, it is helpful to examine the historical connection between the two concepts. Beginning in the thirteenth century, English law held the sovereign immune based on the belief that the king could do no wrong. ${ }^{14}$ In America, the doctrine of sovereign immunity was adopted because it was believed that suits against the government would hamper it from performing its public duty and would deplete public funds. ${ }^{15}$ Thus, the fact that government liability is funded through taxation, unlike private liability, contributed to the adoption of sovereign immunity in America. Although sovereign immunity has been criticized since its entrenchment in American common law, the doctrine survived into the $1960^{\prime} \mathrm{s}^{16}$ The debate shifted in favor of increased government liability after Fleming James introduced the concept of loss spreading. ${ }^{17}$ Indeed, loss spreading has been the primary reason given by contemporary scholars $^{18}$ and courts $^{19}$ for abolishing sovereign immunity.

13. The proposed system of state funding applies only to state common law and statutory tort claims. It does not apply to actions under the U.S. Constitution or federal statutes. The proposal is limited to claims based on state law for two reasons: (1) this Note does not address the values associated with constitutional law and how those values relate to, or supersede, the economic goals of the tort system; and (2) municipal liability arises primarily out of accidents related to common law torts. See infra note 20 and accompanying text.

Because state common law and statutory claims must be treated separately from constitutional and federal statutory claims, this proposal would require that the compensation fund cover damages only for state claims. Municipalities would continue to pay damages for violations of federal law.

14. Birmingham, Sovereign Immunity in Connecticut: Survey and Economic Analysis, 13 CoNN. L. Rev. 293, 293-94 (1981); see also 18 E. MCQuillin \& S. Flanagan, The LAw of Municipal. CoRPORations $\S 53.02$ (3d ed. 1984 \& Supp. 1987) (principle of sovereign immunity appears to have derived from English concept that 'king could do no wrong').

15. Owen v. City of Independence, 445 U.S. 622, 645 n.28 (1980); Birmingham, supra note 14, at 295.

16. Birmingham, supra note 14 , at 293-95.

17. See James, supra note 11; see also Calabresi \& Hirschoff, Toward a Test for Strict Liability in Torts, 81 Yale L.J. 1055, 1082 (1972) (rise of "currently dominant distributional goals" of loss spreading and distribution in favor of victims is connected to increased compensation).

18. 3 K. Davis, Administrative LAw Treatise $\$ 25.17$, at 503 (1958) (government should be held liable more often than private actors because of government's superior ability to spread losses); $P$. SCHUCK, SUING Government 101 (1983) (one justification for expanding governmental liability is increased loss spreading); see also Van Alstyne, Government Tort Liability: A Public Policy Prospectus, 10 UCLA L. Rev. 463, 471-72 (1963); of. E. MCQuIllin \& S. FlanaGan, supra note 14, $\S$ 53.02 , at 153 (sovereign immunity criticized by scholars because economic burden borne by individual). Van Alstyne draws upon the general shift to a risk-spreading rationale in tort law to ground his argument that governments should be held liable for torts. This rationale follows, in turn, from the goals of loss spreading and victim compensation. See James, supra note 11, at 557-58. James, in keeping with his general belief that loss spreading should be a principal goal of tort law, asserts that any rule that extends loss spreading should be adopted unless it increases the accident rate. Harper, James and Gray review systems of general social insurance for tort based on loss spreading, but do not recommend a framework for the implementation of any particular program. 3 F. HARPER, F. JAMES \& O. Gray, The LAw of TORTS \$13.1 (2d ed. 1986). Indeed, all of the commentators cited supra discuss government assumption of liability only from a national/theoretical perspective.

19. See Owen v. City of Independence, 445 U.S. 622 (1980). The court in Owen held that municipalities have no immunity from constitutional violations. In its opinion, the court pointed out that "[n]o longer is 'blameworthiness' the acid test of liability; the principle of equitable loss-spreading has joined fault as a factor in distributing the costs of official misconduct." Id. at 657 ; $c f$. E. MCQuILLIN 
As some of the protections of sovereign immunity have lapsed, municipalities have found themselves exposed to tort claims, principally those arising out of the activities that they perform as a matter of custom. These activities include dispatching police patrol cars, running subway systems, lighting city streets, maintaining city parks, and supervising swimming pools. ${ }^{20}$

\section{Municipal Taxation}

The current system of funding municipal liability is inadequate because its reliance on a regressive taxation system lays a disproportionate burden for tort compensation on those less well-off. In other words, the system relies on regressive taxation and therefore compromises loss spreading. The less regressive the form of taxation used to fund municipal tort liability, the more proportionately ${ }^{21}$ losses are spread throughout society. A shift to non-regressive funding would further loss spreading by assuring that the costs of victim compensation are distributed more proportionately throughout society. ${ }^{22}$

Taxation provides municipalities with the funds to cover liability insurance premiums and adverse damage awards. While taxation is not the only source of revenue for municipalities, other sources, such as intergovernmental revenues or bonds, are earmarked for specific uses and are not generally available for funding tort liability. ${ }^{23}$ In 1985 , forty-nine percent

\& S. FlaNAGAN, supra note $14, \S 53.02$, at 153 (sovereign immunity condemned by jurists because economic consequences borne by individuals).

20. New York City breaks its liability claims into nine major types: defective roadways, defective sidewalks, police action, accidents occurring on school property, medical malpractice, auto accidents, claims by employees, recreation, and accidents occurring on public property. In fiscal year 1986-1987, the major claims types made up $95 \%$ of the total personal injury claims filed against the city. New York City Office of Management and Budget, Statistical Compilation of Claims Against New York City (1988) (on file with author) [hereinafter OMB Study]; see also Mashaw, Civil Liability of Government Officers: Property Rights and Official Accountability, LAw \& CoNTEMP. ProBs., Winter 1978, at 13-14 (proprietary acts induce most government civil liability); Sandoz, Safety: The Watchword for the Eightzes, 9 CuRrent Mun. Probs. 443 (1982-83) (discussing dangers from gas lines, police, and vehicles); Sorry, Your Policy Is Cancelled, supra note 3 (listing types of activities that contribute to insurance crisis); D. Hauser, supra note 3 , at 1 (cities and counties have high contact with people using streets, highways, parks, and beaches).

21. Calabresi argues that the "deep pocket" approach to loss spreading (putting heavier burdens on the wealthy) is better at reducing the secondary costs of accidents (i.e., economic dislocation). $G$. CAlABRESI, supra note 5, at 42 . The proposal in this Note is only concerned with removing the disproportionality (regressiveness) of the funding system. The degree to which the income tax used to fund the proposal should conform to the "deep pocket" model or the proportionality model is a decision best made by state legislatures.

22. The "payouts" of the tort system do not affect loss spreading. Even if low-income persons gain less from the tort compensation system than do those more well-off, a shift to non-regressive taxation would still increase loss spreading because the losses would be spread more proportionately among individuals and municipalities. See $i d$. at 41 (compensation for loss of income favors those more well-off); Priest, supra note 3, at 1552 (poor have low current and prospective incomes and, therefore, tend to recover low damages). This Note focuses on the financing (pay-in) of the tort system, and does not address the configuration of compensation (payout) or the overall equity of the tort system.

23. Federal aid to state and local governments is largely limited to specific projects in the following categories: waste treatment, compensatory education, Medicaid, Social Security, low-income hous- 
of municipal tax revenues were raised through property taxation, ${ }^{24}$ twenty-nine percent through sales taxation, ${ }^{28}$ fourteen percent through income taxation, ${ }^{28}$ and eight percent through other forms of taxation. ${ }^{27}$ Overall, municipal taxation is regressive. ${ }^{28}$

\section{A. Property Taxes}

Property taxation ${ }^{2 \theta}$ is regressive to the extent that it is passed on to renters. ${ }^{30}$ Although property taxes are paid by property owners, some portion of the tax burden is assumed by renters. ${ }^{31}$ Whether as a result of

ing, and transportation. See Bureau of the Census, Statistical AbSTRact of the United STATES 1986, at 269 (1986).

24. Bureau of the Census, City Government Finances in 1985-1986, at 1 (1986) [hereinafter City Government FinanCes].

25. Id.

26. Id. In 1984, only 11 states had municipalities which levied income taxes. In most states only the larger cities (e.g., New York City) did so. See id. at 7-64. In comparison, 46 states levied income taxes (either personal or corporate, or both). Bureau of the Census, State Government FiNANCES IN 1985-86, at 11 (1986) [hereinafter State Government Finances].

The four states that do not currently tax income would undergo a substantial change in their tax structures if they were to adopt this proposal. However, this Note provides those states with a guide for considering adoption of the state-funded plan described here and gives state legislatures substantial flexibility to choose the system best suited to their own state.

27. Grty Government Finances, supra note 24 , at 1.

28. In a study based on 1976 data for all 50 states, Donald Phares analyzed tax incidence (equity) by examining taxation under progressive, regressive, and mainstream assumptions. D. PHARES, Who Pays State and Local Property Taxes? 29-30 (1980). With respect to property taxes-a focal point of the incidence debate-the mainstream assumption lies between the most progressive view of property taxation (property taxes fall on owners of capital) and the most regressive view (property taxes are passed on to renters). The mainstream assumption apportions half the tax to owners of capital and the other half to renters. The mainstream position presents a balanced view of tax incidence and will therefore constitute the basis for presenting Phares' data in this Note. Under the mainstream view, Phares demonstrated that for those earning less than $\$ 3,000$, the overall average effective rate of all local taxation was $12.88 \%$, while those who earned more than $\$ 35,000$ paid a rate of only $3.95 \%$. There was a decrease in the overall rate in direct relation to the increase in income across the income levels. Id. at 90-91. In a 1974 study, Robert Inman and Daniel Rubinfeld evaluated the overall spending and tax equities of local, state, and federal governments. Their study shows that local taxation was regressive. In contrast, state taxes were proportional. Federal government taxation was slightly progressive. Inman \& Rubinfeld, The Judicial Pursuit of Local Fiscal Equity, 92 HaRv. L. REv. 1662, 1692-94 (1979). On the basis of their study, Inman and Rubinfeld concluded that only programs based on income redistribution and centralized financing would result in tax and spending equity. Id. at $1748-49$.

29. Property taxes have been the mainstay of municipal taxation principally because they can be levied without the consent of the state government, unlike income and sales taxes. W. GARDNER, supra note 8 , at 361 . There are at least two reasons why state governments might be reluctant to give municipalities the right to raise sales or income taxes: (1) municipalities with high income flow, but low assessed property values, are better served by the ability to raise sales or income taxes than are poor municipalities; and (2) municipal government sales or income taxes might conflict with existing state sales or income taxes. See supra note 26 (in 11 states where local income taxes are levied, they are collected only by large cities).

Another comparative advantage is that the property tax base is relatively immobile. Since land and buildings cannot be shifted in the event of tax increases, rental values (or property values) will respond relatively slowly to changes in property taxes. W. Hirsch, THE Economics of STATE AND LOCAL GOVERNMENT 95-96 (1970).

30. W. GARDNER, supra note 8, at 395-96 (extent of income-distribution effects depends on portion of income low-income families spend on housing).

31. R. Boadway \& D. Wildasin, Public Sector Economics 437-39 (2d ed. 1979) (due to relative inelasticity of demand for housing, tax burden may be shifted forward to consumers); $E$. 
rent-passing or other factors, the burden of property taxation falls disproportionately upon those in the lower income brackets. ${ }^{32}$

\section{B. Sales Taxes}

Sales taxes are paid by retailers and passed on to consumers through surcharges on purchased goods. Since individuals with lower incomes spend a higher proportion of their disposable income on consumption goods, and thus on sales taxes, sales taxation is regressive. ${ }^{33}$

\section{Income Taxes}

Income taxes affix a marginal tax rate to a given level of earnings. Under an income tax, those with a higher income bear a heavier tax bur-

Browning \& J. BRowning, supra note 8, at 404 (property tax regressive at local level).

32. Although there is some debate about the degree to which property taxes are passed on to renters or property assessments are skewed to favor those more well-off, empirical results reveal the general regressivity of property taxation. In 1976 , persons earning under $\$ 3,000$ paid an effective tax rate of $10.25 \%$ on local property taxes, while those making over $\$ 35,000$ paid a rate of only $2.79 \%$. The decline in rates from $10.25 \%$ to $2.79 \%$ was steady and inversely related to the level of income. $D$. Phares, supra note 28 , at $90-91$.

A more recent study conducted by Phares on New York state and city taxes demonstrates the regressive nature of property taxation in particular and local taxation in general. The overall local property tax rate averaged $20.5 \%$ for individuals making under $\$ 4,200$ and declined steadily to a rate of $3.37 \%$ for those in the $\$ 42,000-49,000$ range, with a slight increase to $4.62 \%$ for those making over \$49,000. D. Phares, Who Pays New York Taxes? 90-91 (Aug. 16, 1985) [hereinafter New York Study] (working paper prepared by staff of New York Legislative Commission on Modernization and Simplification of Tax Administration and Tax Law).

Using 1980 data, Phares also demonstrated that property taxation in Hawaii was regressive. In his study, the effective rate for those earning between $\$ 3,900$ and $\$ 5,199$ was $2.36 \%$. As incomes increased, this rate fell constantly to a low of $0.66 \%$ at the $\$ 32,500-38,999$ level. The effective rate was higher (3.65\%) for those with income over $\$ 100,000$. D. Phares, The Impact of Hawaii's Taxes: A Look at Taxpayer Burden and Equity, at 86 (December 1984) [hereinafter Hawaii Study] (final report available from Hawaii Tax Review Commission).

In a study of Indiana state and local taxes, James Papke's results show that, assuming no shift in the tax burden onto consumers, property taxation in Indiana has been regressive. In 1985, the average effective tax rate for someone earning $\$ 3,001-5,000$ was $5.87 \%$. The rate for those earning more than $\$ 100,000$ was only $3.53 \%$, with the lowest rate $(2.75 \%)$ assessed against those making $\$ 40,001-50,000$. J. Papke, The Composition and Burden of Indiana's TAx System: Interstate CompariSoNS 41 (1987) (report prepared for the Indiana State Teachers Association).

33. In 1976, the average effective tax rate for local sales taxation on individuals with an income under $\$ 3,000$ was $1.07 \%$. This percentage fell as income increased, reaching a low of $0.30 \%$ for those with an income of over \$35,000. D. Phares, supra note 28, at 90-91.

Phares' New York study yielded similar results. The effective local sales and use tax rate for those earning under $\$ 4,200$ was $2.7 \%$, and the percentage declined steadily to a rate of $0.9 \%$ for those earning over $\$ 49,000$. New York Study, supra note 32 , at 85 . 
den than those with a lower income. ${ }^{34}$ Consequently, income taxation is non-regressive. ${ }^{35}$

In addition, taxpayers prefer income taxes to property taxes. In a survey of citizens' attitudes toward various taxation regimes, local property taxation was consistently seen as the least desirable form of taxation, while state income taxation was viewed as the least objectionable. ${ }^{38}$

\section{Implications of Tax Analysis}

The regressive nature of most municipal taxation undercuts the goal of spreading losses. This observation motivates the search for a way to achieve greater loss spreading without detracting from existing levels of deterrence and compensation.

To attack the problem, municipalities could raise non-regressive taxes. However, this approach suffers several defects. Inequities in wealth among municipalities within a state cannot be addressed by non-regressive taxation within a single municipality. Similarly, some municipalities will not be able to fund adverse judgments through income taxation unless they levy extremely high taxes, which may increase the overall regressivity within the system. Finally, municipalities cannot raise or increase their

34. In 1976 , individuals who earned under $\$ 3,000$ paid an average effective rate of $0.01 \%$ in state income taxes. This rate increased steadily, reaching a high of $1.96 \%$ for those earning between $\$ 30,000$ and $\$ 35,000$. There was a difference of more than 190 -fold between the lowest and highest average effective tax rate paid. D. PHAREs, supra note 28 , at $90-91$.

New York state income taxes for 1980 showed similar progressivity. For individuals earning $\$ 4,200-5,999$, the effective tax rate was $0.86 \%$. This rate increased with income, reaching $3.6 \%$ for those earning $\$ 35,000-41,999$. New York Study, supra note 32 , at 71 .

The Hawaii study showed that state income taxes were progressive, but not as markedly as the first two studies might suggest. The effective tax rate for those earning below $\$ 3,900$ was $1.5 \%$. The rate increased to $3.6 \%$ for those making between $\$ 9,100$ and $\$ 10,399$. There was a decrease in the rate for those earning between $\$ 10,400$ and $\$ 38,000$, with a minimum rate of $1.4 \%$. Nevertheless, the rate increased for those earning more than $\$ 39,000$, with the highest rate, $3.7 \%$, levied against those earning more than $\$ 100,000$. Hawaii Study, supra note 32, at 85 .

Papke found that in 1985, the effective Indiana personal income tax rate progressed steadily from $2.25 \%$ to $1.7 \%$ over an income range from $\$ 0-25,000$. For those with higher incomes, the rate fluctuated but generally remained higher than the rate assessed against those with the lowest incomes. $\mathrm{J}$. PAPKE, supra note 32 , at 41.

Recent increases in taxable income, due to the elimination of many federal tax loopholes, have led to greater progressivity in state income taxation. Murray, Many States Target Wealthy to Bear Tax Burden As New U.S. Law Forces Them to Revamp Codes, Wall St. J., Feb. 2, 1987, at 50, col. 1.

35. However, a flat-rate tax without exemptions may be regressive. Those with lower incomes may not be as adept at minimizing their taxable income.

36. In a 1982 survey conducted throughout the continental United States, 1,000 adults were asked which form of taxation they felt was the least fair: federal income taxes, state income taxes, state sales taxes, local property taxes, and "do not know." Of the five choices, local property taxes were seen as the worst form of taxation by $30 \%$ of the sample group, while state income taxes were seen as the most equitable form, with only $11 \%$ labelling them as the worst. This pattern was consistent with attitudes expressed during the preceding decade. Advisory Commission ON INTERgovernMENTAL Relations, Changing Public Attitudes on Governments and Taxes 13 (1982). The distaste for local property taxation has been suggested as one reason for the shift in educational funding and control from local to state governments. J. Harrigan, Politics and Policy in States and ComMUNITIES 265 (1980). 
proportional share of income taxes without permission from the state legislature. $^{37}$

\section{A Proposal for State-Funded Municipal Tort Insurance}

State funding of municipal liability would capitalize on the advantages states have in spreading losses. States are in a better position to spread losses than municipalities for two reasons. First, states have a larger base from which they can draw income tax revenues to fund the system. Second, state funding would facilitate loss spreading from richer municipalities, which generate greater income taxes, to poorer municipalities, which generate less; state funding thus would help ensure non-regressivity. ${ }^{38} \mathrm{~A}$ national system would be preferable if the sole purpose of the program were loss spreading. However, another essential component of the program is deterrence of undesirable behavior through regulatory measures. Since states are closer to municipalities both geographically and institutionally, state governments are in a better position than the federal government to regulate municipal activities. ${ }^{30}$ This proposal presents several options for state legislatures to consider in shaping a response tailored to local needs and preferences. These options include reliance on a tort or compensation system, ${ }^{40}$ fines and compulsory directives, inspections, and

37. See 4 C. SAndS \& M. Libonati, Local Government Law $\$ 23.01$ (1982 \& Supp. 1987) (" $[$ A]bsent a constitutional provision governing the matter, the state legislature is regarded as having a sovereign's free hand in determining the proper allocation of taxing competence between and among the state itself and local government units."); $c f$ infra note 48 (discussing power of states over municipalities).

38. Courts have already taken notice of the disparity in wealth among municipalities and the relationship of this disparity to local financing. Although these cases involve education, rather than municipal liability, they illuminate the legal import of the manner in which local property taxation exacerbates inequities among municipalities.

In 1973, the New Jersey Supreme Court held that New Jersey's system of financing education through property taxation violated the state constitution. Robinson v. Cahill, 62 N.J. 473, 303 A.2d 273 (1973). The court ruled in Cahill that financing public education through property taxes unfairly advantaged wealthier municipalities. The court ordered the implementation of a new system of financing, but left to the legislature the details of its formulation. Several proposals were presented to the court and turned down for failure to meet the New Jersey constitutional standard that there be " $a$ thorough and efficient system of free public schools for the instruction of all the children in the State. . ." Id. at 285 . Finally, the legislature was forced to impose an income tax, the state's first, to meet the standard set by the court. R. LeHNe, The Quest FOR Justice 161-63 (1978).

In San Antonio v. Rodriguez, 411 U.S. 1 (1973), the United States Supreme Court held that the use of property taxation to finance public education did not violate the Fourteenth Amendment's equal protection clause under the "rational basis" test. Id. at 55. Nevertheless, the Court did recognize the need for tax reform in the funding system, although it felt that such a reorganization could be accomplished only through legislative action. Id. at 50-59.

39. The long history of direct interaction (through funding and regulation) between states and municipalities is evident in education, transportation, and land use. See J. HarRigan, supra note 36, at 251-72, 295-317, 319-41; see also infra note 48 (describing legal authority of states over municipalities).

40. Under a state-funded system, compensation could be distributed either through a no-fault system, whereby victims are compensated according to a payout schedule, or through the existing fault-based tort system. See generally Sugarman, supra note 9 (argument for no-fault system). Although the general merits of a no-fault system versus a fault system are the subject of ongoing debate, id., a no-fault system seems particularly well-suited for a state-funded municipal insurance program. 
safety education programs. Each state faces a unique set of conditions produced by the combination of its political environment, tax structure, and fiscal health. This proposal attempts to provide state legislatures with a flexible implementation scheme because the best outcome will be achieved only if states rely to a certain degree on each of the several policy variables. The optimal degree of reliance on each policy variable will be a matter for individual state legislatures to determine.

A no-fault system encompasses a collectivist view of torts, which seems appropriate in the context of communities causing harm to their citizens. Hutchinson, Beyond No-Fault, 73 CAlIf. L. REv. 755, 756 (1985) (no-fault system embraces more collectivist view of compensation than fault system). In addition, one of the principal rationales for having a fault system-deterrence-is not applicable to the proposed program, since deterrence would be achieved through means other than court-awarded damages. See supra Section III (B).

A no-fault system would eliminate many of the transaction costs associated with a court-based tort system: It would involve less reliance on lawyers, and decrease expenditures on litigation. See Sugarman, supra note 9, at 598. Sugarman points out that the administrative costs of the tort system are so high that only half of all liability insurance actually goes to the victim. Id. at 596. Sugarman also describes the cost to the public of judges and the court system. Id.; see also Pierce, Encouraging Safety: The Limits of Tort Law and Government Regulation, 33 VAND. L. REV. 1281, 1323 (1983) (compensation system reduces transaction costs by eliminating certain factual disputes relating to causation). The no-fault mechanism would have the added benefit of making compensation readily available to all victims, since there would be fewer legal obstacles to payment. The guarantee of compensation would mean an effective end to the "lottery" system of compensation currently embodied in the tort system. Franklin, Replacing the Negligence Lottery: Compensation and Selective Reimbursement, 53 VA. L. REv. 774, 778-80 (1967) (likening fault system of compensation to lottery); Pierce, supra, at 1321-22 (move to compensation system eliminates lottery component of fault system). This guarantee would widen the distribution of compensation.

In addition, the current tort system' awards people with low income less compensation on average than people with higher income because damage awards often include lost earnings and pain and suffering; the payout on these damage components is generally greater for those with higher income. Priest, supra note 3, at 1558-59; Stewart, supra note 6, at 188 .

There are advantages to shifting the mode of cost internalization from courts to agencies. Regulatory agencies provide more accurate information for constructing experience ratings. Henderson, $J u d i$ cial Review of Manufacturers' Conscious Design Choices: The Limits of Adjudication, 73 ColuM. L. REv. 1531 (1973) (courts not well suited for role of setting safety standards in general, and manufacturers' safety standards in particular); Pierce, supra, at 1322-23; see infra Section III(B)(2) (proposing use of experience rating to assess fines and target inspections). All accident data relating to municipalities would be funneled through an agency; this procedure would yield more accurate risk assessments than courts could provide. In addition to better data, the proposed regulatory system would allow immediate cost calculation, based on compensation payments and causation analyses, without resort to the judicial system. Pierce, supra, at 1326. Regulatory agencies can use aggregate data to analyze statistical and probabilistic causation. Id. at 1310 . By contrast, much of the evidence presented in a judicial proceeding must be specific to the parties before the court. See G. CALABrESI, supra note 5 , at 256 (fault system likely to ignore recurring cost avoider since it focuses only on particular cost avoider). While an administrative compensation system would not eliminate the need to find some causal relationship between municipal conduct and an injury, proving causation would be much less difficult in an administrative proceeding. Cf. Small, Gaffing at a Thing Called Cause: Medico-Legal Conflicts in the Concept of Causation, 31 TEX. L. REv. 630, 654-56 (1953) (difficulty with causation standard in tort is remedied in workers' compensation system).

Another drawback to employing the tort system as a means of cost internalization is the fact that many victims do not choose for one reason or another to go forward with a lawsuit. If they do initiate a lawsuit, they frequently settle for compensation or find it difficult to prove fault. Calabresi points out that the fault system fails to provide deterrence to the extent that the party at fault does not ultimately bear the full cost of an accident. G. CALABresi, supra note 5, at 250; see also Shavell, A Model of the Optimal Use of Liability and Safety Regulation, 15 RAND J. EcoN. 271, 273 (1984) (using mathematical model to demonstrate that low probability of suit for harm leads to sub-optimal risk reduction). 


\section{A. Financing}

Taxes and fines are the two sources of financing explored in this proposal. State income taxes would be the primary source of funding for municipal tort liability insurance because they are non-regressive. ${ }^{41}$ This system would be based on personal income taxation, rather than pro-rata funding $^{42}$ from municipalities. ${ }^{48}$

Another potential source of financing is the imposition of fines for undesirable behavior. In extreme circumstances, municipalities would pay fines directly to the state. ${ }^{44}$ Legislatures should keep in mind that municipalities would discharge fines by resorting to revenue raised through regressive forms of municipal taxation. ${ }^{45}$ Therefore, fines should be only a minor source of revenue for a state-funded compensation system. ${ }^{16}$ Fines should be imposed not to raise revenues, but rather to deter municipalities from engaging in harmful behavior.

\section{B. Regulatory Scheme}

A system based on state funding of municipal tort damages would provide an excellent opportunity to utilize the efficiencies ${ }^{47}$ of state regulatory authority over localities. ${ }^{48}$ The system should be designed to deal effec-

41. See supra notes 34-35 and accompanying text. The method of insuring is optional. The state could either self-insure or purchase insurance commercially. This flexibility would allow the state to capitalize on low insurance rates when available, while retaining the option to self-insure during times of high premiums and low availability.

42. A pro-rata system would provide financing by collecting funds from individual municipalities according to some standard, e.g., population. A pro-rata system would not resolve the problem of regressive funding, since funds appropriated from municipalities are typically derived from regressive sources. See supra Section II.

43. A contemporary parallel to the plan proposed in this Note is the scheme of social insurance for accidental harms established by New Zealand. Accident Compensation Act, 2 N.Z. Stat. 1409 (1975). The New Zealand plan bars all causes of action for death or personal injury caused by accidents and mandates a no-fault system of state-administered compensation. Henderson, The New Zealand Accident Compensation Reform (Book Review), 48 U. ChI. L. Rev. 781, 781 (1981) (reviewing G. Palmer, Compensation for Incapacity (1979)). Variable levies are assessed on employers and flat rates on the self-employed; variable levies are imposed on motor vehicles for the motor vehicle compensation system; and parliamentary appropriations compensate non-wage earners. Id. at 783. Under the New Zealand plan, the estimated necessary funds for the upcoming year are collected and set aside for funding future claims. The amount is calculated by estimating the value of future accident claims discounted by their present valuc. $I d$. at 786 . The term commonly used for this form of funding is "full funding." See T. Ison, Accident Compensation 134 (1980).

44. See infra Section III(B)(2).

45. See supra Section II (describing overall regressivity of municipal taxation).

46. The amount of the insurance fund composed of fines should be limited to a specified portion of the fund. However, the determination of the fine cap should be made by legislatures, which presumably have the relevant information concerning their individual state's needs. Factors relevant to such a decision would be the health of the state government budget, the relative financial condition of municipalities, and the history of state aid to local governments.

47. See infra note 76.

48. Municipalities are creatures of the states. Therefore, states have plenary power over their municipalities, including the powers to regulate and to levy fines. See United Bldg. \& Constr. Trades Council v. Mayor of Camden, 465 U.S. 208, 215 (1984) (municipality derives all authority from state) (citing City of Trenton v. New Jersey, 262 U.S. 182, 187 (1923) (state regulation levying fee for diversion of waters from stream did not violate contract clause of United States Constitution since 
tively with the relationship between the municipal governmental structure and tortious behavior. ${ }^{49}$

An agency should be established by the legislature through an enabling statute that sets forth the agency's mandate to implement the state's regulatory policy. ${ }^{\mathrm{so}}$ The formation of an agency would allow the legislature to devise the general regulatory framework without exposing itself to interest group pressure regarding the regulatory details. ${ }^{51}$ The agency itself may become subject to special interest pressures. However, this problem could be controlled by taking measures to prevent agency capture. ${ }^{52}$ The regulatory-insurance system proposed in this Note would shift the method of deterrence from a purely market deterrence approach to a combined market/direct deterrence system. ${ }^{53}$ It would consist of three components: (1)

states have plenary power to regulate municipalities)); see also P. ScHuck, supra note 18, at 119 (states are ultimate sources of authority and have power over individual state officials and local governments). Municipalities which would benefit from the state assuming tort funding are unlikely to resist the increased regulation that would accompany funding. The education cases provide ample precedent for a shift of regulatory authority from municipal government to states. See supra note 38. The shift in responsibility for funding education from the local to the state level was accompanied by a corresponding increase in the level of state regulation of local education. While state education agencies ("SEAs") historically exercised little control over local school districts, the emergence of higher levels of state funding has led SEAs to play an increasingly important policy-making role. This regulation has taken the form of minimum competency tests for students, skill tests for teachers, and curriculum requirements, all of which require some form of monitoring by the state. J. HARRIGAN, supra note 36 , at $254,269-70$.

49. As discussed earlier, most municipal torts occur in the course of proprietary functions. See supra note 20 and accompanying text. In municipal governments, policy is formulated by elected officials and implemented by low-level employees-for example, swimming pool attendants, park rangers, and janitors. See Olson, Official Liability and Its Less Legalistic Alternatives, LAw \& CoNTEMP. PROBS., Winter 1978, at 67, (distinguishing governmental decision from implementation by low-level officials). Because it is difficult to monitor or regulate directly the actions of low-level cmployees, this proposal emphasizes the implementation of safety policies. However, legislatures would retain the flexibility to concentrate on regulating either the decision-making unit or the low-level employee.

50. Agency implementation is a common framework for administering regulatory compensation or joint insurance systems. In New Zealand, regulatory authority is vested in the Accident Compensation Commission ("ACC"). Accident Compensation Act of 1972, 2 N.Z. Stat. 1409 (1975). While the ACC plays a role in providing education and setting broad regulatory guidelines, its regulatory function is augmented by Labour Department inspectors. T. Ison, supra note 43 , at 159. The LASIA board, see supra note 3, similarly has authority to "[d]evelop, promulgate, and effectuate loss prevention programs, risk management programs, and safety programs." CAL. Gov'T CoDE $\$$ 6599.09(a) (West Supp. 1988). It is not enough that safety regulations be passed: They must be supplemented by enforcement, safety education, and safety research on the state level. See Sands, Hou Effectue is Safety Legislation?, 11 J. L. \& ECON. 165, 178-79 (1968) (comprehensive state safety regulation of construction industry is insufficient without scientific research and cost studies).

51. See Pierce, Institutional Aspects of Tort Reform, 73 CAl.IF. L. Rev. 917, 932-33 (1985) (legislature can shield itself from pressures by enacting broad policy and empowering agency to formulate specific regulation). This structure would give the agency freedom to promulgate and enforce specific regulatory measures, following the broad guidelines of the legislature, while remaining shielded from political pressure. California's LASIA, described supra note 3, has broad discretionary authority over risk management-a structure analogous to that suggested by this Note. CAL. Gov'T CODE $§ 6599.09$ (a) (West Supp. 1988).

52. Proper employment screening would eliminate the problem of the agency acting as a feeder to special interest organizations and viče versa.

53. See Brown, Deterrence in Tort and No-Fault: The New Zealand Experience, 73 Ca1.IF. L. REv. 976, 979 (1985) (deterrence goal can be met by means other than tort liability); Shavell, On Liability and Insurance, 13 BeL. J. EcoN. 120, 121-22 (1982) (terms and incentives contained in insurance policies can lead to desired level of deterrence). 
state-promulgated safety standards for municipalities; ${ }^{54}$ (2) fines and injunctions levied against municipalities that consistently violate state safety standards or cause a disproportionate number of accidents; ${ }^{\text {ss }}$ and (3) safety education programs directed at low-level municipal employees. ${ }^{\text {so }}$ This tripartite system has the potential both to maintain the present level of deterrence and to increase deterrence through more precise regulation, cost internalization, and accident prevention. ${ }^{87}$

\section{Regulation}

Under the proposed regulatory system, the state agency would promulgate regulations requiring municipalities to meet specified minimum standards. The standards would include safety precautions for public parks, placement of street signs, road maintenance (filling potholes and clearing snow), and limits on the number of people allowed in a public swimming pool area. ${ }^{58}$ These types of regulations would help ensure that municipali-

54. The regulatory scheme could be similar to California's LASIA, described supra note 3. LASIA possesses the authority to implement a system of risk management standards and safety programs similar to those used by commercial insurers. Wasser Interview, supra note 2 . The idea that risk management experts can evaluate municipal safety programs is not new and would be a part of almost every municipal structure if the costs were not prohibitive. See Pribble, Small Cities: Homemade Remedies for High Insurance Rates, 13 CurRent MuN. ProBs. 364, 367 (1986). Nevertheless, a system of effective deterrence would probably require on-site inspection as well.

55. Primary emphasis in setting fines should be placed on the number and severity of regulatory violations, and not on the actual amount of damage awards, if a court-based system is used. Damage awards are subject to jury bias and do not always reflect the extent of wrongdoing. Nevertheless, some legislatures may prefer, or find it necessary, to fine municipalities that have high damage awards assessed against them.

56. See 1 Review by Officials Committee of the Accident Compensation Scheme 114 (1986) [hereinafter ACCIDENT REPORT] (ACC's responsibilities include "creating an interest in safety and accident prevention").

57. G. CALABRESI, supra note 5, at 274-77 (optimal system composed of market and regulatory methods); see also Shavell, supra note 40 . Shavell provides a mathematical model which demonstrates the shortcomings of a system that relies solely upon liability or regulation. Shavell demonstrates that a system that encompasses both liability (cost internalization) and regulation is superior in achieving the optimal level of risk reduction.

Whenever damages are not paid by the tortfeasor, but by some third party, there is a danger of "moral hazard"- the possibility that the tortfeasor will take less care to avoid accidents. See id. at 271, 273-74 (regulatory standard is suboptimal to extent that it deviates from mean (average) optimal amount of care); Wittman, Prior Regulation Versus Post Liability: The Choice Between Input and Output Monitoring, 6 J. Legal. STuD. 193, 202 (1977). The possibility of "moral hazard" under the system proposed by this Note is no greater than it is under the current regime, in which insurance predominates. See C. Heimer, Renctive Risk and Rational Action 35 (1985) (while incentive to avoid losses is transferred to insurer, control over losses remains with insured). But see James, supra note 11, at 559 (attacking notion that protection given by insurance undercuts deterrence).

Some of the steps proposed in this Note to control undesirable behavior are similar to the methods used by insurance companies to curtail "moral hazard." C. HeImer, supra, at 37, 43 (insurance pricing, contracting, and inspection are used in insurance industry as means of controlling moral hazard). These insurance industry policies, which are augmented by research regarding safety and risk, have actually led to increased safety. James, supra note 11, at 559-63; see also Note, Encouraging Safely Through Insurance-Based Incentives: Financial Responsibility for Hazardous Wastes, 96 YALE L.J. 403, 406-07 (1986) (insurers have advantage in analyzing accident-related and safetyrelated data).

58. See Insurance, 13 Current Mun. Probs. 67, 71 (1985) (new loss prevention plan in Al- 
ties, which would no longer absorb the direct costs of tort liability, would not cause an excessive number of accidents. ${ }^{50}$

\section{Cost Internalization}

In cases of extreme malfeasance on the part of a municipality, such as the continuous violation of regulations or intentional misconduct, the state agency should levy fines, ${ }^{60}$ or impose restrictions against the municipality through administrative orders. ${ }^{61}$ Administrative restrictions could range from closing a pool system until proper risk control measures are employed to cordoning off a hazardous city street until it is made safe. ${ }^{62}$ The threat of state-imposed sanctions (fines and restrictions) would enhance deterrence. $^{\text {.3 }}$

bion, Iowa, includes "scheduled checks on playground equipment and traffic signs, along with securing city equipment and tools"); Sandoz, supra note 19, 444-46 (proposed rules regulating natural gas lines include using polyethylene materials for pipe, maintaining records on leaks, and shutting down system to make repairs).

59. A look at the nine major claim types against New York City demonstrates that safety measures related to the provision of basic services could dramatically reduce accidents. In 1987, defective roads and sidewalks, accidents on school property, auto accidents, park-related accidents, and accidents on public property accounted for $\$ 56,827,226(50 \%)$ of the liability claims paid by the city. OMB Study, supra note 20. Regulation would probably be less effective in cases involving police action or medical malpractice. However, even those two classes of torts might be reduced with proper procedural safeguards, such as preventing police from using the choke hold.

Since the regulatory plan is composed of multiple policy variables- direct regulation, and fines and administrative orders-each of which helps to effectuate the desired level of deterrence, costs can be controlled. To the extent that direct regulation is too costly to administer, fines can be emphasized. Again, this alternative gives state legislatures the flexibility to tailor a plan suitable to their needs.

The New Zealand plan also provides a framework for structuring the preferred system. In New Zealand, the Department of Labour sends inspectors out to investigate regulatory violations in the workplace and disseminate safety information. The proposal in this Note sets up a similar type of monitoring system. The New Zealand plan, however, is not wholly effective for three reasons: (1) investigations are not focused on the need for structural changes in workplace design; (2) effective sanctions (fines) are not available for enforcement; and (3) political pressure is not created, since reports are not systematically revealed to labor groups. T. Ison, supro note 43, at 159-62. State legislators should avoid such omissions when they draft laws to implement state-funded municipal liability programs.

60. See Wittman, supra note 57 , at 203 (punishment (fines) for ex ante behavior can alleviate "moral hazard"). In addition, fines are preferable to court judgments because they can be imposed quickly and prospectively.

61. See supra note 48 (power of states over municipalities).

62. See, e.g., Sawyer, supra note 1, at A6, col. 1 (township of Schaghticoke, N.Y., closed down road because it could not afford to make it insurable).

63. State legislators could heighten deterrence either by increasing regulation, or raising penalties associated with regulatory violations. These options allow legislators to structure a desirable system and conirol costs.

New Zealand's Accident Compensation Act of 1972 contains provisions regarding fines and bonuses similar to those proposed in this Note. 2 N.Z. Stat. 1409 (1975). Section 73 of the Act provides for bonuses to be given to, or penalties to be levied against, employers in relation to their accident experience. If an employer has a lower accident rate than those in her category of employers, she may receive a bonus. However, if the employer has a higher rate, she may be forced to pay a fine. Nevertheless, the New Zealand system is inadequate in three respects which state legislators implementing this proposal should avoid: (1) records relating to accident experience are not kept; (2) standards for group comparison are not maintained; and (3) standards for imposing fines are not available. T. IsoN, supra note 43 , at $127-29,173-75$.

Despite its shortcomings, empirical evidence shows that the New Zealand Act has increased deterrence in at least one area-automobile safety. Since the start of the compensation system, the number 
The regulatory agency would compare the records of municipalities to determine which cause accidents and commit regulatory violations disproportionate, in number and severity, to other municipalities. The information on regulatory violations should be gathered by state safety inspectors, who could be part of the agency established to implement regulations. An inspection regime could be designed along the lines of the Occupational Safety and Health Administration's ("OSHA") inspection policy.

OSHA is authorized to make unscheduled inspections. ${ }^{84}$ OSHA ranks inspections in the following order of importance: (1) imminent danger situations, (2) catastrophic and fatality situations, (3) complaint investigations, (4) Target Industry Program and Target Health Program inspections, and (5) random inspections. ${ }^{65}$ A state regulatory agency might follow a similar ranking system, perhaps along the following lines: (1) circumstances involving imminent harm to citizens, (2) systematic violation of regulations or consistently poor experience ratings, and (3) random inspections. Violators should be subjected to follow-up inspections, such as those conducted by OSHA. ${ }^{68}$ Inspectors should be guided in their choice of inspection sites by information on which municipalities had the most frequent and severe liability damages awarded against them, and which municipalities consistently or egregiously violated regulations. In addition, random (unannounced) inspections should be undertaken. ${ }^{67}$ Data on the frequency and severity of tort damages awarded against municipalities should be readily available from records of claims paid out by the state.

The state could use the information gathered to compile a list of the most dangerous municipalities. ${ }^{68}$ At the municipal level, the party out of power could capitalize on the fact that the municipality has been identified as dangerous. This signal would imply that those in power were inca-

and severity (measured in fatalities per vehicle kilometer travelled) of automobile accidents has diminished. The initiation of the New Zealand plan was coupled with increased regulation over driving activity and more efficient monitoring. Brown, supra note 53, at 1000-02.

64. 29 U.S.C. $\$ 666(f)$ (1982). See also B. Walis, Occupational Safety and Health Act 77 (PLI Commercial Law and Practice Course Handbook Series No. 84, 1972) (general discussion of OSHA inspection procedures).

65. Id. at 29.

66. See id. at $85-87$.

67. The Supreme Court has held that "closely regulated" commercial industries may be subject to warrantless searches by states. New York v. Burger, 107 S. Ct. 2636 (1987). It follows that a municipality, although not a "closely regulated" commercial industry, also would not be protected from random inspections by the Fourth Amendment proscription against unreasonable searches and seizures. $C f$. supra note 48 (discussing state regulatory authority over municipalities).

In New Zealand, inspectors from the Department of Labour investigate accidents. T. Ison, supra note 43, at 159. Under California's LASIA program, discussed supra note 3, auditors will monitor safety projects to ensure that municipal safety programs meet state risk management standards. However, the California plan will not prescribe on-site inspections. Wasser Interview, supra note 2 . These two regulatory systems demonstrate the flexibility available to legislatures in implementing the specifics of this proposal: A legislature may choose an on-site system of inspection or a more indirect means of evaluating safety plans.

68. See D. Mueller, Public Choice 117-19 (1979) (examining correlation between voter information and representative behavior). 
pable of ensuring safety and were wasting the voters' money on fines. Because a neutral state agency would compile the data on safety and fines, the political signal would be more legitimate than a compilation by the very officials under attack; furthermore, the information would be more complete than if it had been disseminated by courts. ${ }^{69}$

Legislatures could utilize the monies garnered through fines in several ways. First, the monies could be used to reward municipalities judged by the regulatory agency to exhibit exemplary safety records. This practice would reward municipal governments and their constituencies. Second, the monies could be placed in the general insurance pool to provide compensation for injured victims. Finally, the monies could pay for safety programs, thereby increasing the overall safety level within the state.

\section{Safety Education}

Safety education should play an important role in state regulation. Many of the harms at the municipal level are caused by low-level employees who may not know of, or fully appreciate, existing safety programs and regulations. ${ }^{70}$ To rectify this situation, the state should send teams of safety educators across the state to instruct workers on safety ${ }^{71}$ Education programs could range from advising road workers on how to prevent hazards to teaching park officials proper methods of supervising organized sports activities. ${ }^{2}$ The safety education program would be largely selfperpetuating, since each "generation" of employees, once trained in safety

69. An accident level dissemination system would provide a greater political deterrent than court judgments since court judgments do not usually gain wide publicity unless they are extremely large or controversial.

70. See P. Schuck, supra note 18, at 101-05 (task structure may constrain low-level worker from altering potentially tortious behavior); James, supra note 11, at 557-63. James believes that employees have an incentive to avoid accidents, apart from those brought about by possible liability: Employees risk personal injury or employer discipline for a job poorly done. James stresses that, even with insurance coverage, the "moral hazard" does not prevail for those reasons and also because large insurers have safety programs. See also Sandoz, supra note 20, at 444 (safe operations depend on conscientious employees with adequate training); Schirmer, Why Safety?, 8 Currenr MuN. Probs. 347,349 (1981) (one "personal factor" of accidents is lack of instruction for low-level employees on proper procedures). Of course, safety education alone, without the other components of this proposal, would be insufficient to achieve the desired level of deterrence. $C f$. McCaffrey, Decentralizing Occupational Health and Safety Regulation: An Evaluation of the Foundation and Prospects, 21 CAl. W.L. Rev. 101, 125-27 (1984) (quest to reorient safety attitudes not sufficient to reduce risk in manufacturing).

71. Safety education programs currently occupy the policy agenda of municipalities and are viewed as necessary components of safety programs. Barr \& Rosenthal, A Risk Management Approach for Small and Intermediate Cities, 11 CURREnT MUN. Probs. 45, 47 (1984-85) (need for safety booklet for employees); Sandoz, supra note 20, at 447 (one method of accident prevention is education of municipal workforce on vastness of liability problem); Ward, Accident Prevention for New Employees, 9 CURRENT MUN. Probs. 451 (1982-83) (need to provide orientation program for new employees) see also Kanawaty, Training for a Changing World: Some General Reflections, 124 INT'L LAB. REV. 401,407 (1985) (need for training within workplace).

72. In New Zealand, the program attempts to create an interest in safety by disseminating information and conducting safety campaigns. ACCIDENT REPORT, supra note 56, at 114; T. Ison, supra note 43, at 159 . 
skills, could in turn train incoming workers. Therefore, safety education may well turn out to be substantially a one-time investment.

Regulation is a direct (result-oriented) means of preventing undesirable behavior. A system of regulation that would address the need to control municipalities, which might otherwise seek to abuse a state-funded insurance program, would effectively guard against excessive tortious behavior; therefore, deterrence would be assured.

\section{Evaluation of the Proposal}

This Section explores consequences of the proposal not previously examined so that legislators can make a fully informed decision whether, and in what form, to adopt these recommendations.

\section{A. Advantages}

In addition to furthering the goal of loss spreading and maintaining the goals of deterrence and compensation, the state-funded system has other advantages. State funding would increase compensation, ensure implementation of adequate safety programs, provide a long-term solution to the problem of insurance unavailability, and contribute to rational formulation of tort policy.

Shifting liability to the state level would increase compensation because state funds would be available even if the municipal tortfeasor were underinsured. ${ }^{73}$ A state-funded insurance system would be an improvement over the current system, under which some poorer municipalities may be judgment-proof against large claims due to a limited revenue base and an inability to insure effectively ${ }^{74}$ The size of a state's tax base permits it to self-insure more easily than municipalities can.

The proposed system would ensure that even the smallest city would have a risk control program. Currently, many small cities cannot afford risk control programs and consequently face the danger of a higher accident rate, as well as exposure to liability suits. ${ }^{75}$ States have more resources to channel into safety education and inspection programs than do

73. See generally supra note 2 (plight of uninsured cities). Insufficient insurance is a concern because large awards may bankrupt municipalities with small budgets-for instance, Schaghticoke, N.Y. See Sawyer, supra note 1 , at A6, col. 6 ( $\$ 800,000$ town budget).

74. The shift of funding to the state level, in conjunction with state regulatory measures, may lower the risk level of municipal activities. For underinsured municipalities, market deterrence will not produce the desired result because the full cost of accidents cannot be internalized; only the amount equivalent to assets may be internalized. This means that if a municipality obtains insurance for $\$ 1$ million of liability, and its ability to pay damages for torts is limited by financial constraints, it will take precautions that prevent only the first $\$ 1$ million in damages. Therefore, if the desired level of deterrence exceeds $\$ 1$ million, the municipality is not undertaking enough deterrence-related activity. S. Shavel,t, Economic ANAlysis of Accident LAw 279-80 (1987); Wittman, supra note 57, at 204.

75. Pribble, supra note 54, at 364 (small cities rarely able to afford risk management programs). 
individual municipalities. In addition, centralization under the control of the state would make these programs more cost-effective. ${ }^{78}$

Finally, a state-funded insurance regime would protect municipal governments from the vagaries of insurance business cycles. ${ }^{77}$

\section{B. Possible Disadvantages}

This proposal calls for an increase in government spending on safety and regulatory programs. The increased costs are associated with forming and funding an agency to regulate safety. Nevertheless, these costs are justifiable because they further the goals of tort law. Increased spending on safety may be called for, regardless of state assumption of liability, because of the benefits that accrue to municipalities and their citizens from risk management. ${ }^{78}$ In addition, any increase in revenues needed to fund the program should be partially offset by a corresponding decrease in property taxes.

Legislatures may be tempted to change tort laws to limit municipal liability. However, changes in tort laws are not necessarily detrimental. ${ }^{79}$ Moreover, once state legislatures have evaluated this proposal on its merits and recognized its advantages, it would be inconsistent for them to change laws solely to decrease compensation.

\section{Conclusion}

In looking for answers to the problems of municipal tort liability and the lack of available insurance, state legislatures are searching for solutions without thoroughly considering the goals underlying tort law ${ }^{80}$ Legislatures should respond to these issues in a manner that is fundamentally sound in terms of meeting the goals of the tort law system. State assumption of responsibility for municipal tort funding through non-regressive state income tax revenues would allow legislatures to further the goal of loss spreading without compromising existing levels of compensation and deterrence. This end could be accomplished within a framework that allows each legislature to tailor a program to the needs of its own state. In addition, the proposal provides a long-term solution to current and future

76. The state should be even more effective at analyzing such data due to economies of scale and institutional advantages. See C. HEIMER, supra note 57, at 206 (sometimes cheaper to collectivize safety programs).

77. See generally supra note 2 (some municipalities forced to go without insurance).

78. See supra Section III(B)(3) (need to increase safety education programs).

79. If full internalization of tort costs leads legislatures to revise tort rules, the new system of rules would be more efficient than the earlier system because the rules would be based on more precise information.

In the past, states have not resisted possible tort liability. As of 1978, 44 states and the District of Columbia had abolished sovereign immunity either judicially or statutorily in whole or in part. Birmingham, supra note 14, at 295; see also E. MCQuiluIN \& S. FLANAGAN, supra note 14, §53.02 (discussing judicial and legislative abrogation of sovereign immunity).

80. See supra note 3. 
insurance crises by shielding municipalities from the gyrations of commercial insurance availability. 
